\title{
ANALISIS KEMAMPUAN BERPIKIR LOGIS MATEMATIS SISWA PADA MATERI SISTEM PERSAMAAN LINEAR DUA VARIABEL
}

\author{
Mustafa A.H. Ruhama ${ }^{1}$, Nurya Yasin ${ }^{2}$, Karman La Nani ${ }^{3}$ \\ ${ }^{1,3}$ Program Studi Pendidikan Matematika, Fakultas Keguruan dan Ilmu Pendidikan, Universitas Khairun \\ Jalan Bandara Babullah, Kampus 1 Unkhair, Akehuda Ternate, Indonesia \\ ${ }^{2}$ SMP Negeri 1 Kota Ternate \\ Jalan A.I.S Nasution No.26, GamalamaTernate, Indonesia \\ e-mail: ${ }^{1}$ mustafaruhama@ unkhair.ac.id; \\ Submitted: August 20, 2020 \\ Revised: September 27, 2021 \\ Accepted: September 28, 2021 \\ corresponding author*
}

\begin{abstract}
This study aims to describe the mathematical logical thinking ability of students of SMP Negeri 1 Ternate on systems of linear equations in two variables materials. This research uses a qualitative research. Subject of this study were three students of class VIII-J SMP Negeri 1 Ternate. The data collection stage was conducting tests, categorizing students according to the KBLM level based on the test results, and conducting interviews with research subjects. The data analysis used in this study was to analyze the data from the test results and interviews. The results showed that students at KBLM Level 2 were able to say and write down what was known and what was asked about the questions correctly, were able to use the steps to solve systems of linear equations in two variables and these steps were correct, were able to provide arguments about all steps-steps to solve systems of linear equations in two variables, and be able to draw conclusions correctly on the final answer. Students at KBLM Level 2 were able to say and write down what was known and not write down what is asked, able to use the steps to solve systems of linear equations in two variables and these steps are correct, able to provide arguments about all steps to solve systems of linear equations in two variables, and able to draw conclusions correctly on the final answer. Students at KBLM Level 2 were able to say and write down what was known and not write down what is asked, can use the steps to solve systems of linear equations in two variables but make calculation errors in these steps, do not provide arguments about all the steps solve systems of linear equations in two variables, and do not draw conclusions correctly on the final answer.
\end{abstract}

Keywords: mathematical logical thinking ability, systems of linear equations in two variables

\section{Pendahuluan}

Mata pelajaran matematika yang diajarkan kepada siswa pada pendidikan formal untuk membekali siswa agar memiliki kemampuan atau kompetensi yang memadai sehingga dapat beradaptasi dengan perubahan jaman di masa yang akan datang. Hal ini sesuai dengan Peraturan Menteri Pendidikan dan Kebudayaan Nomor 58 Tahun 2014 Tentang Kurikulum 2013 Sekolah Menengah Pertama/Madrasah Tsanawiyah yang menyatakan bahwa mata pelajaran yang diberikan mulai dari sekolah dasar, untuk membekali siswa dengan kemampuan berpikir logis, analitis, sistematis, kritis, inovatif dan kreatif, serta kemampuan bekerjasama. Kompetensi tersebut diperlukan agar siswa dapat memiliki kemampuan memperoleh, mengelola, dan memanfaatkan informasi untuk hidup lebih baik pada keadaan yang selalu berubah, tidak pasti, dan sangat kompetitif.

Kemampuan berpikir logis mempunyai peranan penting dalam pembelajaran matematika di Sekolah Menengah Pertama (SMP). Kemampuan berpikir secara logis merupakan salah satu kemampuan yang ingin dicapai dalam pembelajaran matematika di SMP (Andriawan dan Budiarto, 2014), meningkatkan pemecahan masalah dan pembelajaran konsep matematika (Saragih, 2007; Usdiyana dkk, 2009; Rahmawati dan Kurniasari, 2016; Fitriyah, dkk 2019) dan meningkatkan hasil atau prestasi belajar (Puspitasari dkk, 2019).

Berpikir logis merupakan kemampuan sesorang untuk menarik kesimpulan dari masalah dengan menggunakan argumen yang sesuai dengan langkah-langkah menyelesaikan masalah. Siswono (2008) mengatakan berpikir logis dapat diartikan

Copyright $\odot$ Authors. This is an open access article distributed under the Attribution-NonCommercialShareAlike 4.0 International (CC BY-NC-SA 4.0), which permits unrestricted use, distribution, and reproduction in any medium, provided the original work is properly cited. 
sebagai kemampuan siswa untuk menarik kesimpulan yang sah menurut aturan logika dan dapat membuktikan kesimpulan itu benar (valid) sesuai dengan pengetahuan-pengetahuan sebelumnya yang sudah diketahui. Menurut Albrecht, berpikir logis adalah proses mencapai kesimpulan menggunakan penalaran secara konsisten (Sumarmo, 2012). Berpikir logis adalah suatu proses berpikir dalam menarik kesimpulan yang berupa pengatahuan berdasarkan fakta yang ada dengan menggunakan argumen yang sesuai dengan langkah dalam menyelesaikan masalah hingga didapat suatu kesimpulan (Andriawan dan Budiarto, 2014; Rahmawati dan Kurniasari, 2016). Menurut Sholiha (2011), ada 3 karakteristik berpikir logis, yaitu (1) keruntunan berpikir: siswa dapat menentukan langkah yang ditempuh dengan teratur dalam menyelesaikan permasalahan yang diberikan dari awal perencanaan hingga didapatkan suatu kesimpulan, (2) kemampuan berargumen: siswa dapat memberikan argumennya secara logis sesuai dengan fakta atau informasi yang ada terkait langkah perencanaan masalah dan penyelesaian masalah yang ditempuh, dan (3) penarikan kesimpulan: siswa dapat menarik suatu kesimpulan dari suatu permasalahan yang ada berdasarkan langkah penyelesaian yang telah ditempuh.

Sistem persamaan linear dua variabel merupakan salah satu materi yang diajarkan di kelas VIII SMP. Materi sistem persamaan linear dua variabel lebih sering disajikan soal cerita yakni suatu pemasalahan matematika yang disajikan dalam bentuk kalimat dan berhubungan dengan permasalahan sehari-hari (Yulianto, dkk 2019). Siswa dapat membuat kesimpulan dari masalah pada sistem persamaan linear dua variabel menggunakan argumen yang sesuai dengan langkah-langkah dalam menyelesaikan masalah. Oleh karena itu, siswa akan menggunakan kemampuan berpikir logis yang meliputi keruntutan berpikir, kemampuan berargumen, dan penarikan kesimpulan dalam menyelesaikan soal sistem persamaan linear dua variabel. Tujuan dalam penelitian ini adalah mendeskripsikan kemampuan berpikir logis matematis siswa pada materi sistem persamaan linear dua variabel.

\section{Metode Penelitian}

Penelitian ini menggunakan pendekatan kualitatif. Pendekatan kualitatif ini dipilih karena (1) peneliti dapat membuat interpretasi kemampuan berpikir logis matematis siswa, (2) peneliti dapat mengumpulkan data lapangan dimana para siswa dapat memunculkan kemampuan berpikir logis matematis siswa serta
(3) peneliti dapat mendeksripsikan level kemampuan berpikir logis matematis siswa seperti Tabel 1 berikut.

Tabel 1. Level Kemampuan Berpikir Logis Matematis

\begin{tabular}{|c|c|}
\hline $\begin{array}{c}\text { Level } \\
\text { KBLM }\end{array}$ & Indikator \\
\hline Level 2 & $\begin{array}{l}\text { Siswa mampu menyebutkan dan } \\
\text { menuliskan apa yang diketahui serta apa } \\
\text { yang ditanyakan soal dengan tepat. } \\
\text { Siswa mampu mengungkapkan secara } \\
\text { umum semua langkah yang akan } \\
\text { digunakan dalam penyelesaian soal sistem } \\
\text { persamaan linear dua variabel dan } \\
\text { langkah-langkah tersebut benar. } \\
\text { Siswa mampu memberikan argumen } \\
\text { mengenai seluruh langkah-langkah } \\
\text { penyelesaian yang akan digunakan. } \\
\text { Siswa mampu menarik kesimpulan } \\
\text { dengan tepat pada hasil akhir jawaban }\end{array}$ \\
\hline Level 1 & $\begin{array}{l}\text { Siswa mampu menyebutkan dan } \\
\text { menuliskan apa yang diketahui dengan } \\
\text { tepat serta tidak menulsikan apa yang } \\
\text { ditanyakan. } \\
\text { Siswa mampu mengungkapkan secara } \\
\text { umum semua langkah yang akan } \\
\text { digunakan dalam penyelesaian soal sistem } \\
\text { persamaan linear dua variabel dengan } \\
\text { tepat. } \\
\text { Siswa mampu memberikan argumen } \\
\text { mengenai seluruh langkah-langkah } \\
\text { penyelesaian yang akan digunakan. } \\
\text { Siswa mampu menarik kesimpulan } \\
\text { dengan tepat pada hasil akhir jawaban. }\end{array}$ \\
\hline Level 0 & $\begin{array}{l}\text { Siswa mampu menyebutkan dan } \\
\text { menuliskan apa yang diketahui dengan } \\
\text { tepat serta tidak menuliskan apa yang } \\
\text { ditanyakan. } \\
\text { Siswa dapat mengungkapkan secara } \\
\text { umum semua langkah yang akan } \\
\text { digunakan dalam penyelesaian masalah } \\
\text { tetapi melakukan kesalahan perhitungan } \\
\text { dalam langkah-langkah tersebut. } \\
\text { Siswa tidak dapat memberikan argumen } \\
\text { mengenai seluruh langkah-langkah } \\
\text { penyelesaian yang akan digunakan dari } \\
\text { awal hingga mendapat kesimpulan dengan } \\
\text { benar. } \\
\text { Siswa tidak dapat menarik kesimpulan } \\
\text { dengan tepat pada hasil akhir jawaban. }\end{array}$ \\
\hline
\end{tabular}

Subjek dalam penelitian ini adalah siswa kelas VIII-J SMP Negeri 1 Kota Ternate Tahun Pelajaran 2019/2020. Peneliti menetapkan 3 siswa sebagai subjek penelitian. Pemilihan 3 siswa menjadi subjek penelitian berdasarkan pertimbangan siswa sudah memperoleh materi sistem persamaan linear dua variabel dan dapat berkomunikasi secara lisan dan tulisan.

Instrumen utama dalam penelitian adalah peneliti sendiri, karena peneliti yang merencanakan, melaksanakan, mengumpulkan 
data melalui tes dan wawancara, menganalisis data, dan menarik kesimpulan. Instrumen pendukung penelitian adalah tes kemampuan berpikir logis dan pedoman wawancara. Tahap pengumpulan data, yaitu peneliti melakukan tes, mengkategori siswa sesuai dengan Level KBLM berdasarkan hasil tes, dan melakukan wawancara kepada subjek penelitian. Analisis data, yaitu menganalisis data hasil tes dan wawancara. Berdasarkan hasil tes, peneliti mengkategori siswa pada level KBLM, yaitu level 2, level 1, dan level 0. Selanjutnya, melakukan wawancara pada subjek pada level 2, level, 1 dan level 0 untuk mengetahui argumen dalam menyelesaikan soal tes.

\section{Hasil dan Pembahasan}

\subsection{Subjek S1 memiliki KBLM Level 2}

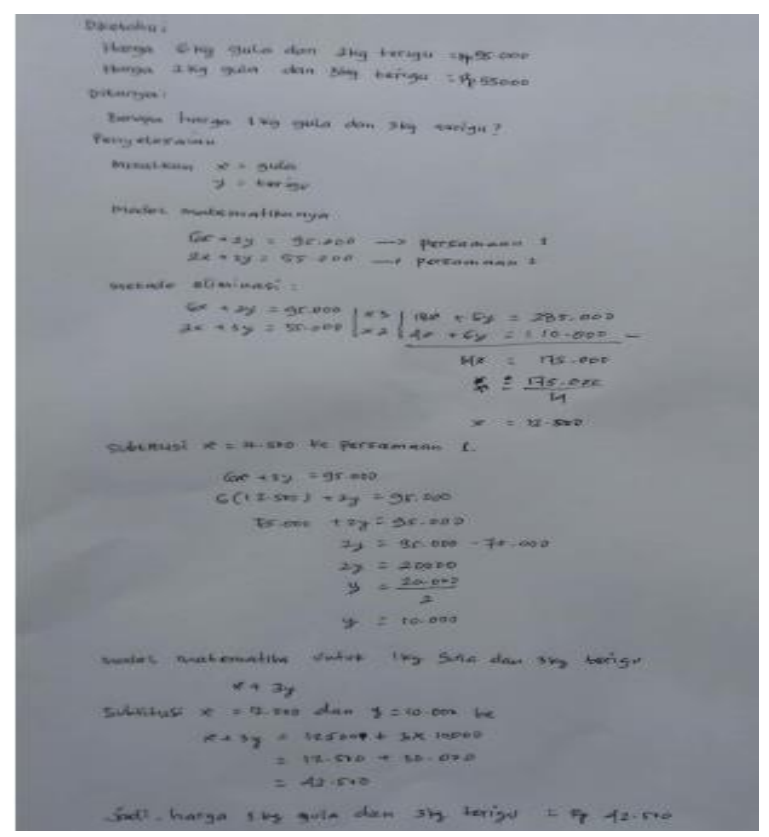

Gambar 1. Jawaban Subjek S1

Dari Gambar 1, S1 menyebutkan dan menuliskan apa yang diketahui serta apa yang ditanyakan soal dengan tepat, menggunakan langka-langkah untuk menyelesaikan soal sistem persamaan linear dua variabel dengan benar, memberikan argumen pada langkah-langkah penyelesaian, dan menarik kesimpulan dengan tepat. Adapun hasil wawancara peneliti dengan subjek S1 sebagai berikut:

\footnotetext{
$\mathrm{P} \quad$ : Informasi apa yang ada dalam soal?

S1 : Yang diketahui harga $6 \mathrm{~kg}$ gula dan $2 \mathrm{~kg}$ terigu sama dengan Rp. 95.000, harga $2 \mathrm{~kg}$ gula dan $3 \mathrm{~kg}$ terigu sama dengan $\mathrm{Rp}$. 55.000 .

$\mathrm{P} \quad$ : Apa yang ditanyakan pada soal tersebut?

$\mathrm{S} 1$ : Berapa harga untuk $1 \mathrm{~kg}$ gula dan $3 \mathrm{~kg}$ terigu
}

P : Bagaimana langkah-langkah penyelesaian soal tersebut?

S1 : Misalkan harga gula adalah $x$ dan harga terigu adalah $y$. Kemudian membuat model matematikanya seperti berikut.

$$
\begin{array}{r}
6 x+2 y=95.000 \\
2 x+3 y=55.000 \\
6 x+2 y=95.000 \text { adalah }
\end{array}
$$

persamaan ke-1 dan $2 x+3 y=55.000$ persamaan ke-2

$\mathrm{P}$ : Setelah membuat model matematikanya, selanjutnya bagaimana langkah-langkah penyelesaian soal tersebut?

S1 : Mengeliminasi variabel $y$ sehingga diperoleh $x=12.500$. Subtitusikan $x=$ 12.500 ke persamaan ke-1 atau ke-2. Pilih subtitusi $x=12.500$ ke persamaan ke-1 sehingga diperoleh $y=10.000$. Model matematika untuk $1 \mathrm{~kg}$ gula dan $3 \mathrm{~kg}$ terigu, yaitu $x+3 y$. Subtitusi $x=$ 12.500 dan $y=10.000$ ke $x+3 y$ sehingga diperoleh 42.500

$\mathrm{P}$ : Kesimpulan dari soal atau permasalahan tersebu?

$\mathrm{S} 1$ : Harga $1 \mathrm{~kg}$ gula dan $3 \mathrm{~kg}$ terigu adalah Rp. 42.500

Berdasarkan hasil tes seperti pada Gambar 1 dan wawancara, subjek S1 memiliki KBLM Level 2, yaitu mampu menyebutkan dan menuliskan apa yang diketahui serta apa yang ditanyakan soal dengan tepat, mampu menggunakan langkah-langkah untuk menyelesaikan soal sistem persamaan linear dua variabel dan langkah-langkah tersebut benar, mampu memberikan argumen mengenai seluruh langkah-langkah menyelesaikan soal sistem persamaan linear dua variabel, dan mampu menarik kesimpulan dengan tepat pada hasil akhir jawaban.

Menurut Evitasari (2017), siswa kategori tinggi mampu menyebutkan apa yang diketahui dan ditanyakan dengan tepat., dapat membuat model matematika serta dapat menyusun rencana penyelesaian dengan menggunakan metode eliminasi atau subtitusi untuk menyelesaikan permasalahan, dan mampu melaksanakan langkahlangkah yang digunakan secara tepat sehingga hasil akhir yang diperoleh juga tepat. Menurut Rahmawati dan Kurniasari (2016), siswa dengan kategori tinggi dapat menyebutkan seluruh informasi yang ada meliputi apa yang diketahui dan apa yang ditanyakan pada soal dengan tepat, siswa juga dapat mengungkapkan secara umum rencana atau langkah-langkah yang akan digunakan.

Selain itu, menurut Andriawan dan Budiarto (2014), siswa dengan kategori tinggi mampu memberikan argumen mengenai seluruh 
langkah-langkah penyelesaian yang akan digunakan dan mampu menarik kesimpulan dengan tepat pada hasil akhir jawaban. Oleh karena itu, berdasarkan pendapat Evitasari (2017), Rahmawati dan Kurniasari (2016), dan Andriawan dan Budiarto (2014) bahwa subjek S1 memiliki KBLM Level 2 dapat dikategori sebagai siswa yang mempunyai kemampuan berpikir logis matematis tinggi.

\subsection{Subjek S2 memiliki KBLM Level 1}

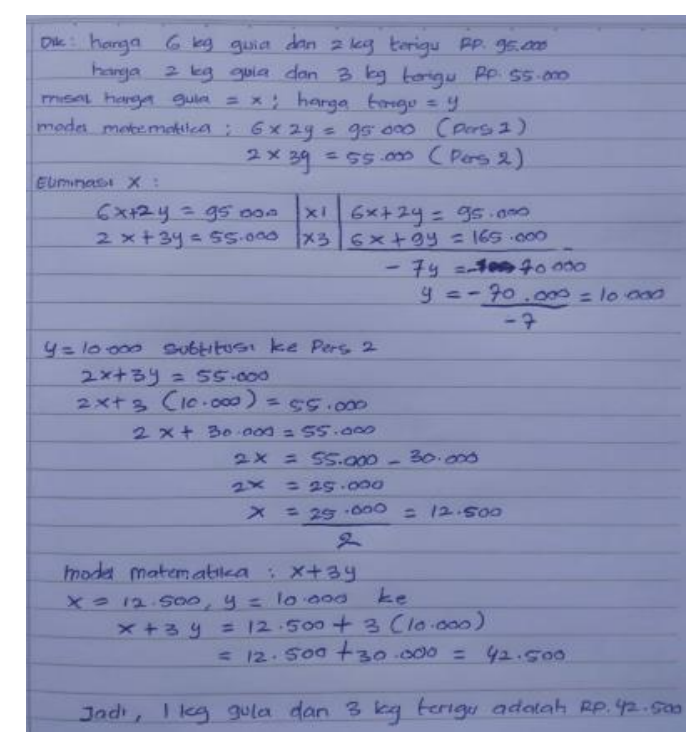

Gambar 2. Jawaban Subjek S2

Dari Gambar 2, S2 menyebutkan dan menuliskan apa yang diketahui dengan tepat dan tidak menuliskan apa yang ditanyakan, menggunakan langka-langkah untuk menyelesaikan soal sistem persamaan linear dua variabel dengan benar, memberikan argumen pada langkah-langkah penyelesaian, dan menarik kesimpulan dengan tepat. Adapun hasil wawancara peneliti dengan subjek S2 sebagai berikut:

$\mathrm{P} \quad$ : Informasi apa yang ada dalam soal?

S2 : Yang diketahui harga $6 \mathrm{~kg}$ gula dan $2 \mathrm{~kg}$ terigu sama dengan Rp. 95.000, harga $2 \mathrm{~kg}$ gula dan $3 \mathrm{~kg}$ terigu sama dengan Rp. 55.000 .

$\mathrm{P} \quad$ : Apa yang ditanyakan pada soal tersebut?

S2 : Harga untuk $1 \mathrm{~kg}$ gula dan $3 \mathrm{~kg}$ terigu

P : Coba lihat kembali pekerjaan Anda apakah yang ditanyakan dalam soal tersebu Anda tuliskan?

S2 : Ternyata yang ditanyakan saya tidak tuliskan

$\mathrm{P} \quad$ : Kenapa tidak dituliskan?

S2 : Lupa

P : Selanjutnya, bagaimana langkah-langkah Anda dalam menyelesaikan soal tersebut?

S2 : Saya memisalkan harga gula sama dengan $\mathrm{x}$ dan harga terigu sama dengan $\mathrm{y}$. Selanjutnya, buat model matematikanya seperti berikut. $6 x+2 y=95.000$ sebagai persamaan 1 dan $2 x+3 y=55.000$ sebagai persamaan 2 .

P : Setelah membuat model matematikanya, langkah selanjutnya?

S2 : Menggunakan metode eliminasi dalam hal ini mengeliminasi variabel $\mathrm{x}$ sehingga diperoleh $\quad \mathrm{y}=10.000$. Selanjutnya, menggunakan metode subtitusi, yaitu subtitusikan $\mathrm{y}=10.000$ ke persamaan kedua sehingga diperoleh $\mathrm{x}=12.500$. Langkah berikut buat model matematika untuk $1 \mathrm{~kg}$ gula dan $3 \mathrm{~kg}$ terigu, yaitu $x+3 y$. Subtitusi variabel $x=12.500$ dan $\mathrm{y}=10.000$ ke $\mathrm{x}+3 \mathrm{y}$ sehingga diperoleh 42.500

P : Dapatkah Anda memberikan kesimpulan dari soal atau permasalah tersebu?

S2 : Iya, harga $1 \mathrm{~kg}$ gula dan $3 \mathrm{~kg}$ terigu adalah Rp. 42.500

Berdasarkan hasil tes seperti pada Gambar 2 dan wawancara, S2 memiliki KBLM Level 1 yaitu mampu menyebutkan dan menuliskan apa yang diketahui dengan tepat serta tidak menuliskan apa yang ditanyakan, mampu menggunakan langkah-langkah untuk menyelesaikan soal sistem persamaan linear dua variabel dan langkah-langkah tersebut benar, mampu memberikan argumen mengenai seluruh langkah-langkah menyelesaikan soal sistem persamaan linear dua variabel, dan mampu menarik kesimpulan dengan tepat pada hasil akhir jawaban.

Menurut Evitasari (2017), siswa kategori sedang mampu menyebutkan apa yang diketahui dengan tepat, dapat membuat model matematika dan dapat menyusun recana penyelesaian dengan menggunakan metode eliminasi atau subtitusi untuk menyelesaikan permasalahan. Menurut Andriawan dan Budiarto (2014), siswa dengan kategori sedang dapat menyebutkan apa yang diketahui pada soal dengan tepat dan siswa dapat mengungkapkan secara umum rencana atau langkah-langkah yang akan digunakan.

Selain itu, menurut Rahmawati dan Kurniasari (2016), siswa dengan kategori sedang mampu memberikan argumen mengenai seluruh langkah-langkah penyelesaian yang akan digunakan dan mampu menarik kesimpulan dengan tepat pada hasil akhir jawaban. Oleh karena itu, berdasarkan pendapat Evitasari (2017), Rahmawati dan Kurniasari (2016), dan Andriawan dan Budiarto (2014) bahwa subjek S2 memiliki KBLM Level 1 dapat dikategori sebagai siswa yang mempunyai kemampuan berpikir logis matematis sedang.

\subsection{Subjek S2 memiliki KBLM Level 1}




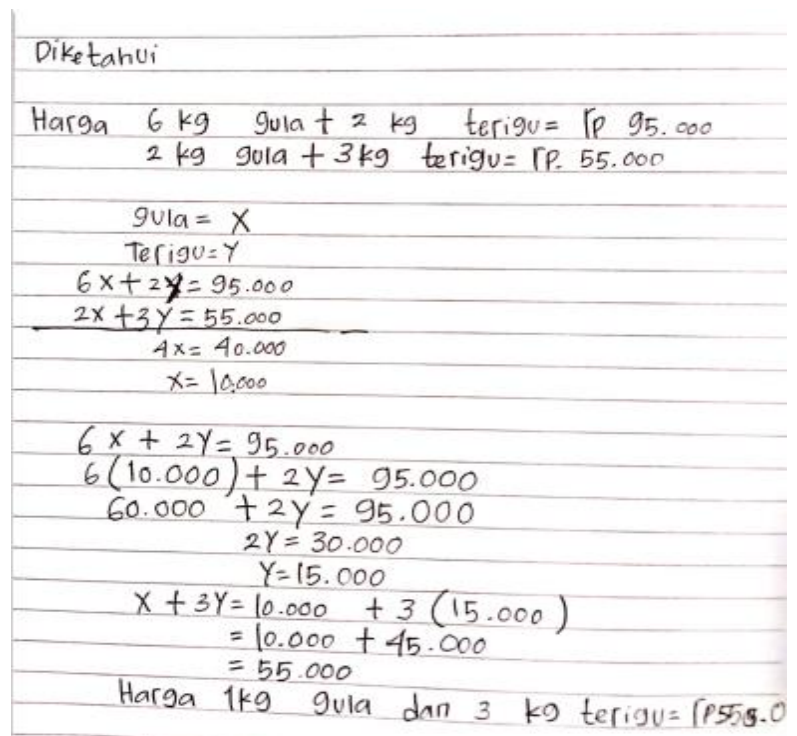

Gambar 3. Jawaban Subjek S3

Dari Gambar 3, S3 menyebutkan dan menuliskan apa yang diketahui dengan tepat dan tidak menuliskan apa yang ditanyakan, menggunakan langka-langkah untuk menyelesaikan soal sistem persamaan linear dua variabel tetapi melakukan kesalahan perhitungan dalam langkah-langkah tersebut, tidak memberikan argumen pada langkah-langkah penyelesaian, dan tidak menarik kesimpulan dengan tepat. Adapun hasil wawancara peneliti dengan subjek S3 sebagai berikut:

\begin{tabular}{|c|c|c|}
\hline $\mathrm{P}$ & : & Informasi apa yang ada dalam soal? \\
\hline S3 & : & $\begin{array}{l}\text { Diketahui harga } 6 \mathrm{~kg} \text { gula dan } 2 \mathrm{~kg} \text { terigu } \\
\text { sama dengan Rp. } 95.000 \text {, harga } 2 \mathrm{~kg} \text { gula } \\
\text { dan } 3 \mathrm{~kg} \text { terigu sama dengan Rp. } 55.000 .\end{array}$ \\
\hline $\mathrm{P}$ & : & Apa yang ditanyakan pada soal tersebut? \\
\hline S3 & : & Harga untuk $1 \mathrm{~kg}$ gula dan $3 \mathrm{~kg}$ terigu \\
\hline $\mathrm{P}$ & ： & $\begin{array}{l}\text { Coba lihat kembali pekerjaan Anda } \\
\text { apakah yang ditanyakan dalam soal } \\
\text { tersebu Anda tuliskan? }\end{array}$ \\
\hline S3 & : & $\begin{array}{l}\text { Ternyata yang ditanyakan saya tidak } \\
\text { tuliskan }\end{array}$ \\
\hline $\mathrm{P}$ & : & Kenapa tidak dituliskan? \\
\hline S3 & : & Lupa \\
\hline $\mathrm{P}$ & : & $\begin{array}{l}\text { Selanjutnya, bagaimana langkah-langkah } \\
\text { Anda dalam menyelesaikan soal tersebut? }\end{array}$ \\
\hline S3 & : & $\begin{array}{l}\text { Saya misalkan harga gula sama dengan } x \\
\text { dan harga terigu sama dengan y. } \\
\text { Selanjutnya, } \quad \text { saya } \\
6 x+2 y=95.000 \text { dan } 2 x+3 y=55.000\end{array}$ \\
\hline $\mathrm{P}$ & : & $\begin{array}{lrr}\begin{array}{l}\text { Apakah } \\
2 x+3 y=55.000\end{array} & \text { merupakan } \\
\text { matematikanya? } & & \text { model } \\
& & \end{array}$ \\
\hline S3 & : & Iya, model matematikanya \\
\hline $\mathrm{P}$ & $\cdot$ & $\begin{array}{l}\text { Coba lihat kembali pekerjaan Anda } \\
\text { apakah model matematika tersebut Anda } \\
\text { tuliskan? }\end{array}$ \\
\hline S3 & : & Saya tidak tuliskan \\
\hline
\end{tabular}

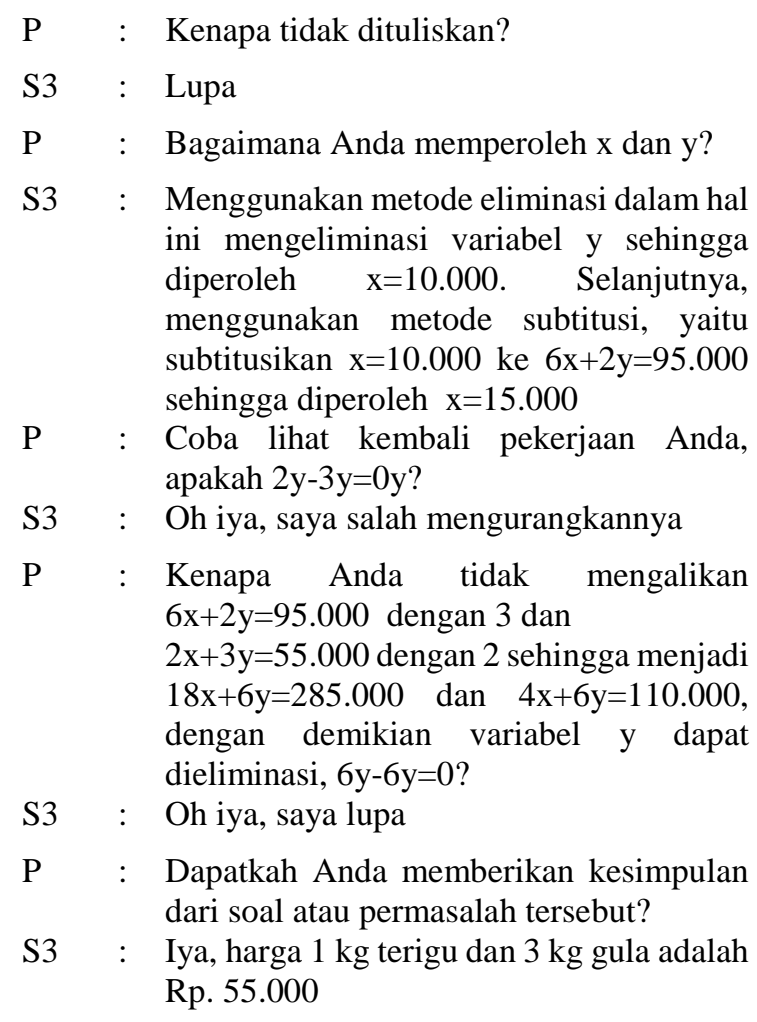

Berdasarkan hasil tes pada Gambar 3 dan wawancara, subjek S3 memiliki KBLM Level 0 yaitu mampu menyebutkan dan menuliskan apa yang diketahui dengan tepat serta tidak menuliskan apa yang ditanyakan, dapat menggunakan langkahlangkah untuk menyelesaikan soal sistem persamaan linear dua variabel tetapi melakukan kesalahan perhitungan dalam langkah-langkah tersebut, tidak memberikan argumen mengenai seluruh langkah-langkah menyelesaikan soal sistem persamaan linear dua variabel, dan tidak menarik kesimpulan dengan tepat pada hasil akhir jawaban.

Menurut Evitasari (2017), siswa kategori rendah mampu menyebutkan apa yang diketahui dengan tepat dan tidak menuliskan apa yang ditanyakan, dapat membuat model matematika dan dapat menyusun recana penyelesaian dengan menggunakan metode eliminasi atau subtitusi untuk menyelesaikan permasalahan tetapi melakukan kesalahan perhitungan dalam langkahlangkah tersebut. Menurut Rahmawati dan Kurniasari (2016), siswa kategori rendah dapat mengungkapkan secara umum langkah penyelesaian yang digunakan tetapi melakukan kesalahan perhitungan pada langkah penyelesaian.

Menurut Andriawan dan Budiarto (2014), siswa dengan kategori rendah hanya memberikan argumen pada beberapa langkah penyelesaian dan tidak dapat memberikan argumen pada hasil akhir yang diberikan. siswa kategori rendah tidak dapat menarik kesimpulan dengan tepat pada hasil akhir jawaban (Andriawan dan Budiarto, 2014; 
Rahmawati dan Kurniasari, 2016). Oleh karena itu, berdasarkan pendapat Evitasari (2017), Rahmawati dan Kurniasari (2016), dan Andriawan dan Budiarto (2014) bahwa subjek S3 memiliki KBLM Level 0 dapat dikategori sebagai siswa yang mempunyai kemampuan berpikir logis matematis rendah.

\section{Kesimpulan}

Siswa pada KBLM Level 2 mampu menyebutkan dan menuliskan apa yang diketahui serta apa yang ditanyakan soal dengan tepat, mampu menggunakan langkah-langkah untuk menyelesaikan soal sistem persamaan linear dua variabel dan langkah-langkah tersebut benar, mampu memberikan argumen mengenai seluruh langkah-langkah menyelesaikan soal sistem persamaan linear dua variabel, dan mampu menarik kesimpulan dengan tepat pada hasil akhir jawaban.

Siswa pada KBLM Level 1 mampu menyebutkan dan menuliskan apa yang diketahui dengan tepat serta tidak menuliskan apa yang ditanyakan, mampu menggunakan langkahlangkah untuk menyelesaikan soal sistem persamaan linear dua variabel dan langkah-langkah tersebut benar, mampu memberikan argumen mengenai seluruh langkah-langkah menyelesaikan soal sistem persamaan linear dua variabel, dan mampu menarik kesimpulan dengan tepat pada hasil akhir jawaban.

Siswa pada KBLM Level 0 mampu menyebutkan dan menuliskan apa yang diketahui dengan tepat serta tidak menuliskan apa yang ditanyakan, dapat menggunakan langkah-langkah untuk menyelesaikan soal sistem persamaan linear dua variabel tetapi melakukan kesalahan perhitungan dalam langkah-langkah tersebut, tidak memberikan argumen mengenai seluruh langkahlangkah menyelesaikan soal sistem persamaan linear dua variabel, dan tidak menarik kesimpulan dengan tepat pada hasil akhir jawaban.

\section{Daftar Pustaka}

Andriawan, B \& Budiarto, M.T. (2014). Identifikasi Kemampuan Berpikir Logis Dalam Pemecahan
Masalah Matematika Pada Siswa Kelas VIII-1 SMP Negeri 2 Sidoarjo. MATHEdunesa, 3 (2), 42-48.

Evitasari, I. P. (2017). Kemampuan Pemecahan Masalah Sistem Persamaan Linier Dua Variabel Ditinjau Dari Kecerdasan Logis Matematis dan Gender. Prosiding Seminar Nasional Integrasi Matematika dan Nilai Islami 2017, 617-621. Malang: UIN Maulana Malik Ibrahim.

Fitriyah, D. M., Indrawatiningsih, N., \& Khoiri, M. (2019). Analisis Kemampuan Berpikir Logis Matematis Siswa SMP Kelas VII dalam Memecahkan Masalah Matematika Ditinjau dari Gaya Belajar. JEMS (Jurnal Edukasi Matematika dan Sains), 7(1), 1-14.

Puspitasari, I. W., Fauzan, G. A., \& Bernard, M. (2019). Penerapan PBL Dengan RME Berbatuan Software Geogebra untuk Meningkatkan Kemampuan Berpikir Logis Matematik Siswa SMP. Journal On Education, 1 (4), 679-687.

Rahmawati, K. N., \& Kurniasari, I. (2016). Profil Berpikir Logis Siswa Dalam Memecahkan Masalah Matematika Menggunakan Test Of Piaget's Logical Operations (TLO) Ditinjau Dari Kemampuan Matematika. MATHEdunesa, 3 (5), 200-209.

Saragih, S. (2007). Mengembangkan Kemampuan Berpikir Logis Dan Komunikasi Matematik Siswa Sekolah Menengah Pertama Melalui Pendekatan Matematika Realistik. Disertasi. Bandung: Universitas Pendidikan Indonesia.

Sholiha, N. (2011). Kemampuan Berpikir Logis Siswa dalam Pemecahan Masalah Matematika Siswa Kelas VII-C SMP Negeri 12 Surabaya. Skripsi tidak dipublikasikan. Surabaya: Universitas Negeri Surabaya.

Siswono, T. Y. E. (2008). Model Pembelajaran Berbasis Pengajuan dan Pemecahan Masalah Untuk Meningkatkan Kemampuan Berpikir Kreatif. Surabaya: Unesa University Press.

Sumarmo, U, dkk. (2012).Kemampuan Dan Disposisi Berpikir Logis, Kritis, Dan Kreatif Matematik (Eksperimen Terhadap Siswa Sma Menggunakan Pembelajaran Berbasis Masalah Dan Strategi Think-Talk-Write). Jurnal Pengajaran MIPA, 17 (1), 17-33.

Usdiyana, D., Purniati, T., Yulianti, K., \& Harningsih, E. (2009). Meningkatkan Kemampuan Berpikir Logis Siswa Smp Melalui Pembelajaran Matematika Realistik. Jurnal Pengajaran MIPA, 13 (1), 1-14.

Yulianto, G. D, Suastika, I. K., \& Fayeldi, T. (2019). Analisis Kemampuan Pemecahan Masalah Matematika Berdasarkan Langkah Polya Pada Materi Sistem Persamaan Linear Dua Variabel. Pi: Mathematics Education Journal, 2 (1), 7-13. 